\title{
RESEARCH
}

Open Access

\section{Effect of different plant extracts and nanoparticles on Thrips tabaci (Lind.) (Thysanoptera: Thripidae) under field conditions and their allelopathic potential on the onion, Allium cepa L. using bioassays and RAPD analysis}

\author{
Sameer H. Qari ${ }^{1 *}$ (D, Abdelhalem H. Khalil ${ }^{2}$, Nilly A. H. Abdelfattah² and Ayman A. Shehawy ${ }^{1,2}$
}

\begin{abstract}
The present study was conducted to investigate the toxicity of Aerosil $200^{\circledR}$ (fumed silica nanoparticles) and leaf extracts of four plants, Cinnamomum camphora, Matricaria chamomilla, Mentha arvensis, and Trigonella foenumgraecum against Thrips tabaci (Lind.) (Thysanoptera: Thripidae) in onion fields, as well their allelopathic effects on onions; moreover, the chlorophyll, phenol, and protein contents were determined in onions. This study was performed in completely randomized plots. After a growth period of 1 month, bioassay investigations and molecular polymorphism in T. tabaci by RAPD-PCR were performed, and total chlorophyll, phenol, and protein concentrations were investigated in onion plants posttreatment as well. The initial reduction\% of the T. tabaci population in onion fields after application of a high concentration of nanoparticles (Aerosil $200^{\circledR}(4 \mathrm{ml} / \mathrm{l})$ ) and 8000 ppm concentrations of the four plant extracts were 83.66, 81.08, 86.92, 74.49, and 91.38\%, respectively, whereas their persistence effects were $73.18,67.78,71.46,66.94$, and $78.29 \%$, respectively. Furthermore, the total chlorophyll contents in onions treated with the nanoparticles and four plant extracts were 1.35, 1.17, 1.09, 1.07, and 1.18 mg/g, respectively; additionally, the concentrations of phenols were $4.65,3.15,3.15,2.85$, and $3.70 \mathrm{mg} / \mathrm{g}$ in onions treated with C. camphora, M. chamomilla, M. arvensis, T. foenum-graecum, and Aerosil 200 ${ }^{\oplus}$, respectively. The C. camphora extract was the most potent, as it increased the protein content in the onion plants, while the Aerosil $200^{\circledR}$ decreased the protein content in onions. In addition, DNA-RAPD showed that the polymorphism percentages were 73, 71, and 67\% when treated with high concentrations of C. camphora and M. arvensis extracts and Aerosol 200 ${ }^{\circledR}$, respectively. T. foenum-graecum and $M$. chamomilla extracts induced the least polymorphism (17 and 16\%, respectively). Overall, this study indicated that these plant extracts as well as the nanoparticles in Aerosil $200^{\circledR}$ could be used to reduce onion infestations of $T$. tabaci in the field environment.
\end{abstract}

Keywords: Thrips tabaci, Onion, RAPD-PCR, Nanoparticles, Plant extracts, Allelopathy, Aerosil 200 ${ }^{\oplus}$

\footnotetext{
*Correspondence: shqari@uqu.edu.sa

'Biology Department, Aljumum University College, Umm Al - Qura University,

Makkah, Saudi Arabia

Full list of author information is available at the end of the article
} 


\section{Background}

The onion (Allium cepa L.) is an important vegetable crop cultivated worldwide. Egypt is considered the largest dehydrated onion source in Africa and the Middle East. Iris yellow spot virus (IYSV) transmission via Thrips tabaci (Lind.) (Thysanoptera: Thripidae) has been reported in many countries, including Egypt (Abdelkhalek et al. 2019). Furthermore, onion plants are considered one of the main origins of dietary polyphenols worldwide (Knekt et al. 1996), and their consumption leads to the protection of DNA against oxidation. Polyphenols in dietary plants showed very important antioxidant activities (Singh et al. 2009). Additionally, they protect organisms from/against cellular damage (Martínez et al. 2007).

Devastating losses of annual onion crops occur due to disease transmission and can range from nonsignificant amounts of loss up to more than $50 \%$ of the total crop, depending upon many factors. Iris yellow spot virus is the most important disease transmitted by $T$. tabaci (Abdelkhalek et al. 2019). Disease symptoms of Iris yellow spot virus are similar to those of $T$. tabaci infestation and appear as eye-like, chlorotic, or diamondshaped lesions (Pappu et al. 2008). T. tabaci is among the major insect pests of onion crops and cause large amounts of damage to the crop by consuming the plant sap and/or by transmitting other diseases, including IYSV (Gent et al. 2006). Control strategies of T. tabaci include chemical insecticide treatments (Jensen 2005).

Heavy application and indiscriminate uses of chemical pesticides in insect pest management has led to the advancement of resistance in all classes of insecticides (Kranthi et al. 2002). On the other hand, using natural plant oils are encouraged in order to decrease the application of chemical pesticides and their residues (Murray et al. 2011).

Allelopathy (largely of secondary metabolites) refers to the harmful or beneficial effects of a plant on another plant through biochemical release from the plant parts, and the release of such chemicals may attract or repel insects. Additionally, allelopathy can affect many plant bionomics, including growth, plant succession, and plant productivity (Singh et al. 2001). Allelochemicals are the secondary metabolites of allelopathic organisms (Hanan M. 2016). Recently, plant extracts have been used for pest control as alternatives to chemical pesticides (Qari and Abdel-Fattah 2017). Several molecular techniques have been used to determine the ability of these plant extracts to reduce insect infestation. Random amplification polymorphism DNA PCR (RAPD-PCR) could be a good technique for the rapid identification of genetic changes on the molecular level (Qari 2010). RAPD-PCR has also been used to determine variations in the T. tabaci genome (Ramakrishnan et al. 2019). Moreover, plants offer a different and alternative source of insect biocontrol agents, as they contain a wide range of bioactive materials, and many of such compounds are selective or have no harmful effects on nontargeted organisms as well as the environment, unlike synthetic insecticides. Additionally, some of these bioactive materials have been shown to have repellent, antifeedant, and toxic effects and induce enzymatic changes in insects (Adakole and Adeyemi 2012).

This study was carried out to evaluate the effect of plant extracts and Aerosil $200^{\circ}$ nanoparticles in reducing onion infestations of T. tabaci in the field using bioassays and molecular tools.

\section{Materials and methods}

\section{Plant extracts and tested material preparation}

The effects of the leaf extracts of four plants, namely, Cinnamomum camphora, Matricaria chamomilla, Mentha arvensis, and Trigonella foenum-graecum, on the infestation of T. tabaci in an onion field, as well as their allelopathic effects on the onion plants, were studied. According to Qari (2008), powdered leaves of each plant were soaked in liquid nitrogen and $1000 \mathrm{ml}$ distilled water for $72 \mathrm{~h}$ at room temperature for aqueous extraction and then kept in a dark at $4{ }^{\circ} \mathrm{C}$. The solutions were filtered and evaporated via rotary evaporation until the extracts were jelly-like in appearance and reach a final concentration of $1 \mathrm{~g} / \mathrm{l}(1000 \mathrm{ppm})$. Two different concentrations were calculated and prepared (4000 and $8000 \mathrm{ppm}$ ) to be used in the bioassay.

On the other hand, nanoparticles (ca. 6.6-13.3 nm: Aerosil $200^{\circ}$ as a silica oxide nanopowder, 99.8\% $\mathrm{SiO}_{2}$ ) was obtained from a commercial company in Egypt for scientific services (Tiba Company). The shape and size of the nanoparticles were verified by electron microscopy and prepared at two concentrations, $4 \mathrm{ml}$ and 2 $\mathrm{ml} / \mathrm{l}$ in order to be use in the bioassays.

\section{Experimental design}

Studies which evaluate the effects of different plant extracts, as well as Aerosil $200^{\circ}$ nanoparticles, on T. tabaci in onion cultivation fields and their allelopathic effects on the onions were carried out at Kaha Agricultural Research Station Farm, Egypt, in March 2018. The onion cultivar Giza 20 was obtained from the Agricultural Research Center, Giza, Egypt. A backpack sprayer was used as for foliar spray. Onions were grown in completely randomized plots in the field; each treatment was repeated four times, and each replicate area was $4 \mathrm{~m} \times 4$ m. After 2 months of onion cultivation, the bioassay investigations were performed; concentrations of 4000 ppm ( $8 \mathrm{ml} / 2 \mathrm{l} / 64 \mathrm{~m}$ for each treatment) and $8000 \mathrm{ppm}$ (16 ml/2 l/64 $\mathrm{m}$ for each treatment) were applied for the plant extracts, while the implemented concentrations of Aerosil $200^{\circ}$ were $2 \mathrm{ml} / \mathrm{l}(4 \mathrm{ml} / 2 \mathrm{l} / 64 \mathrm{~m})$ and $4 \mathrm{ml} / \mathrm{l}(8$ 
$\mathrm{ml} / 2 \mathrm{l} / 64 \mathrm{~m}$ ). All tested materials were prepared and applied as foliar sprays on onions in the morning. Pretreatment counting in each plot was carried out, then the application performed and the reduction\% of $T$. tabaci adults were counted after $1,3,7$, and 10 days and corrected according to Henderson and Tilton (1955).

\section{Onion parameter analyses}

All biochemical studies were carried out on new onion leaves after applications of both concentrations of the botanical extracts (4000 ppm and $8000 \mathrm{ppm})$ and Aerosil $200^{\circ}(2$ and $4 \mathrm{ml} / \mathrm{l})$.

\section{Total chlorophyll}

The assessment of total chlorophyll content was estimated in $85 \%$ acetone leaf extracts according to Metzner et al. (1965). First, the leaves were centrifuged at 14000 $\mathrm{rpm}$, for $20 \mathrm{~min}$ then the absorbance was read spectrophotometrically at 663, 652, 646, and $470 \mathrm{~nm}$. Finally, the concentrations of chlorophyll were calculated according to the following equation (Metzner et al. 1965): total chlorophyll $(\mu \mathrm{g} / \mathrm{ml})=\mathrm{A} 652 \times 27.8$.

\section{Determination of phenols}

One gram of onion leaves was ground in liquid nitrogen, extracted with $80 \%$ methanol (v/v) and heated at $85{ }^{\circ} \mathrm{C}$ for $2 \mathrm{~h}$. After cooling, phenol determination in the extracted leaves was estimated according to Denre (2014).

\section{Protein content}

According to Qari (2016), the protein content of each treated and untreated onion sample was estimated.

\section{RAPD-PCR protocol}

\section{Sampling of T. tabaci and DNA extraction}

Adult insects of $T$. tabaci were collected from different treated onions by shaking the treated plants onto a white sheet to gather the insects. The samples of $T$. tabaci were crushed and stored in TE buffer at $-20{ }^{\circ} \mathrm{C}$ until DNA extraction. DNA was extracted according to the procedure described Oliveira et al. (2010). The insects were ground in liquid nitrogen, dissolved in $4 \% \mathrm{CTAB}$ extraction buffer, mixed with $4 \mu \mathrm{L} \beta$-mercaptoethanol, and then heated for $30 \mathrm{~min}$ at $65^{\circ} \mathrm{C}$. After centrifugation at $14000 \mathrm{rpm}$ for $5 \mathrm{~min}$, the supernatant was treated with cold isopropanol $(\mathrm{v} / \mathrm{v})$ for $20-30 \mathrm{~min}$ then centrifuged again at $14000 \mathrm{rpm}$ for $5 \mathrm{~min}$. DNA samples were precipitated, and the resulting precipitate was washed twice with $70 \%$ alcohol and resuspended in $0.1 \mathrm{ml}$ TE buffer. The quality of the isolated DNA was quantified with a fluorometer and $0.8 \%$ agarose gel stained with 0.2 $\mu \mathrm{g} / \mathrm{ml}$ ethidium bromide (EB) visualized under UV light.

\section{RAPD-PCR analysis}

The RAPD-PCR procedure was carried out on a final volume of $25 \mu \mathrm{l}$ reaction mixture containing $20 \mathrm{ng}$ genomic DNA, $1.5 \mu \mathrm{l}$ PCR buffer $(50 \mathrm{mM} \mathrm{KCl}, 12 \mathrm{mM}$ $\mathrm{MgCl}_{2}, 100 \mathrm{mM}$ Tris-Cl, $\mathrm{pH}$ 9.0), $7.92 \mu \mathrm{l}$ sterile deionized water, $1.8 \mu \mathrm{l}$ dNTPs ( $0.1 \mathrm{mM}$ each), $1.8 \mu \mathrm{l}$ decamer primers (Operon Tech) as shown in Table $1(4 \mathrm{mM})$, and 1.5 U Taq DNA polymerase. PCR was conducted in a Perkin-Elmer TC480 thermocycler as follows: one cycle at $94{ }^{\circ} \mathrm{C}$ for $2 \mathrm{~min} ; 45$ cycles at $94{ }^{\circ} \mathrm{C}$ for $10 \mathrm{~s}, 36$ ${ }^{\circ} \mathrm{C}$ for $30 \mathrm{~s}, 72{ }^{\circ} \mathrm{C}$ for $1 \mathrm{~min}$; and a final extension at 72 ${ }^{\circ} \mathrm{C}$ for $2 \mathrm{~min}$. The PCR products were separated by electrophoresis in $1 \%$ agarose gel, stained with $\mathrm{EB}$, and visualized under UV and documented using Gel Documentation System software (Bio Rad, USA). Each primer yielding productive bands was repeated twice. Band sizes were specified by a DNA ladder.

\section{Statistical analysis}

Analysis of variance ANOVA was implemented with SPSS software. The percentage of DNA stability was estimated according to the following equation: $100-(100 \mathrm{a} \div \mathrm{n})$, according to Luceri et al. (2000), where $n$ is the number of total bands in the control and a is the RAPD-PCR polymorphic bands detected in each treatment sample. The average for each treatment was used for evaluation. The reduction\% was calculated according to Henderson and Tilton (1955) with the following equation:

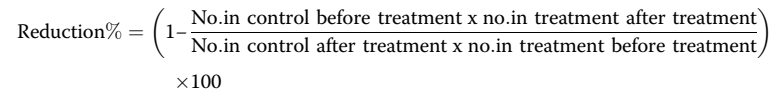

\section{Results and discussion}

Average number of $T$. tabaci after treatment

The results presented in Table 2 showed that the average number of $T$. tabaci adults ranged from $46.9 \pm 4.4$ to $28.55 \pm 5.9$ in the untreated control, while it ranged from $2.95 \pm 0.9$ to $9.55 \pm 1.7,8.45 \pm 3.1$ to $12.9 \pm 4.2,4.75 \pm 1.9$ to $11.95 \pm 4.4$, and $6.45 \pm 3.7$ to $12.65 \pm 3.9$ when 8000 ppm C. camphora, M. chamomilla, $M$. arvensis, and $T$.

Table 1 List of RAPD-PCR primer sequences

\begin{tabular}{lll}
\hline No & Primer name & Sequences $5^{\prime} \rightarrow 3^{\prime}$ \\
\hline 1 & OPA/08 & GTGACGTAGG \\
2 & OPA/11 & CAATCGCCGT \\
3 & OPA $/ 16$ & AGCCAGCGAA \\
4 & OPA $/ 19$ & CAAACGTCGG \\
5 & OPAl/21 & CACGCGAACC \\
6 & OPAL/20 & AGGAGTCGGA \\
7 & OPAB/09 & GGGCGACTAC \\
8 & OPH/11 & CTTCCGCAGT \\
\hline
\end{tabular}


Table 2 Average number and reduction\% of Thrips tabaci after application of plant extracts and Aerosil $200^{\circledR}$ in an onion field compared to that of the control field

\begin{tabular}{|c|c|c|c|c|c|c|c|c|c|c|c|}
\hline \multirow{2}{*}{$\begin{array}{l}\text { Compound } \\
\text { concentration }\end{array}$} & \multicolumn{2}{|c|}{ Aerosil $200^{\circledR}$} & \multicolumn{2}{|c|}{$\begin{array}{l}\text { Trigonella foenum- } \\
\text { graecum }\end{array}$} & \multicolumn{2}{|c|}{ Mentha arvensis } & \multicolumn{2}{|l|}{$\begin{array}{l}\text { Matricaria } \\
\text { chamomilla }\end{array}$} & \multicolumn{2}{|c|}{$\begin{array}{l}\text { Cinnamomum } \\
\text { camphora }\end{array}$} & \multirow[t]{2}{*}{$\begin{array}{l}\text { Untreated } \\
\text { control }\end{array}$} \\
\hline & $2 \mathrm{ml} / \mathrm{l}$ & $4 \mathrm{ml} / \mathrm{l}$ & 4000 ppm & 8000 ppm & 4000 ppm & 8000 ppm & 4000 ppm & 8000ppm & 4000 ppm & 8000 ppm & \\
\hline re-treatment & $41.65 \pm 5.2$ & & $41.05 \pm 4.8$ & & $43.75 \pm 3.6$ & & $39.9 \pm 3.5$ & & $41.25 \pm 4.2$ & & $46.9 \pm 4.4$ \\
\hline After 24 hrs & $13.95 \pm 3.4$ & $5.65 \pm 1.8$ & $15.5 \pm 3.6$ & $6.45 \pm 3.7$ & $14.75 \pm 3.0$ & $4.75 \pm 1.9$ & $17.35 \pm 3.6$ & $8.45 \pm 3.1$ & $11.1 \pm 2.4$ & $2.95 \pm 0.9$ & $38.95 \pm 4.1$ \\
\hline eduction \% & 59.67 & 83.66 & 54.53 & 81.08 & 59.40 & 86.92 & 47.64 & 74.49 & 67.59 & 91.38 & - \\
\hline ter 3 days & $8.2 \pm 1.8$ & $3.65 \pm 1.4$ & $10.95 \pm 3.9$ & $3.9 \pm 2.1$ & $10.9 \pm 4.5$ & $3.45 \pm 2.3$ & $14.1 \pm 3.5$ & $5.35 \pm 3.1$ & $5.7 \pm 2.3$ & $2 \pm 1.1$ & $34.95 \pm 7.7$ \\
\hline eduction \% & 73.58 & 88.24 & 64.20 & 87.25 & 66.56 & 89.41 & 52.75 & 82.00 & 81. & 93. & - \\
\hline fter 7 days & $11.3 \pm 3.1$ & $6.35 \pm 1.9$ & $12.2 \pm 2.9$ & $8.85 \pm 3.9$ & $12.5 \pm 5.3$ & $8.55 \pm 1.6$ & $14.65 \pm 3.9$ & $7.25 \pm 3.3$ & $11.9 \pm 4.6$ & $5.5 \pm 1.8$ & $30.4 \pm 6.7$ \\
\hline$\%$ & 8.14 & 76.478 & 54.14 & 66.73 & 55.92 & 69.85 & 43.35 & 71.96 & 55.49 & 79.42 & - \\
\hline After 10 days & $17.1 \pm 2.4$ & $11.45 \pm 2.6$ & $18.65 \pm 3.4$ & $12.65 \pm 3.9$ & $17.25 \pm 5.2$ & $11.95 \pm 4.4$ & $22.45 \pm 5.0$ & $12.9 \pm 4.2$ & $13.5 \pm 3.2$ & $9.55 \pm 1.7$ & $28.55 \pm 5.9$ \\
\hline eduction \% & 32.55 & 54.83 & 25.36 & 49.37 & 35.22 & 55.12 & 28.15 & 46.88 & 46.32 & 61.96 & - \\
\hline
\end{tabular}

Average number \pm SD (standard deviation)

foenum-graecum extracts were used, respectively. Moreover, the average number of T. tabaci ranged from $5.65 \pm$ 1.8 to $11.45 \pm 2.6$ over a period of $1-10$ days after application of $4 \mathrm{ml}$ of Aerosil 200. Furthermore, the average number of $T$. tabaci adults ranged from $11.1 \pm 2.4$ to 13.5 $\pm 3.2,17.35 \pm 3.6$ to $22.45 \pm 5.0,14.75 \pm 3.0$ to $17.25 \pm$ $5.2,15.5 \pm 3.6$ to $18.65 \pm 3.4$, and $13.95 \pm 3.4$ to $17.1 \pm 2.4$ when 4000 ppm C. camphora, M. chamomilla, M. arvensis, and T. foenum-graecum leaf extracts and Aerosil 200 were applied, respectively. Overall, it was found that the efficacy of the different plant extracts and Aerosil 200 varied due to the nature of the extract and the concentration used.

\section{Reduction percentages of $T$. tabaci after application of botanical extracts and Aerosil $200^{\circ}$}

The data in Table 2 show that the reduction\% of $T$. tabaci individuals 10 days after application was 61.96$46.32, \quad 46.88-28.15, \quad 55.12-35.22, \quad 49.37-25.36$, and $54.83-32.55 \%$ when high and low concentrations of $C$. camphora, M. chamomilla, M. arvensis, and T. foenumgraecum leaf extracts and Aerosil 200 were applied, respectively, while the initial reduction\% was 91.38-67.59, $74.49-47.64,86.92-59.40,81.08-54.53$, and 83.66$59.67 \%$ after 1 day when high and low concentrations of the extracts and Aerosil $200^{\circ}$ were used, respectively. The most efficient essential oils were those obtained from Mentha pulegium, with estimated $\mathrm{LC}_{50}$ and $\mathrm{LC}_{90}$ values of 3.1 and $3.8 \mathrm{mg} \mathrm{l}^{-1}$ air, while those of Thymus mastichina were 3.6 and $4.6 \mathrm{mg} \mathrm{l}^{-1}$ air, respectively (Stepanycheva et al. 2019).

\section{Comparison based on initial and persistence reduction, potency level, and control index of Aerosil $200^{\circ}$ and four} phytochemical extracts on $T$. tabaci in onion fields

The data shown in Table 3 indicate that the initial reduction\% (after 24 h) of T. tabaci in onion fields after application of the highest concentration of Aerosil 200 and $T$. foenum-graecum, M. arvensis, M. chamomilla, and C. camphora was 83.66, 81.08, 86.92, 74.49, and $91.38 \%$, respectively, while their persistence was 73.18 , $67.78,71.46,66.94$, and $78.29 \%$, respectively.

Regarding the relative potency level of the initial reduction, the fold changes are shown in Table 4, it was found that the potency levels of $C$. camphora, $M$. arvensis, Aerosil $200^{\circ}$, and $T$. foenum-graecum were respectively 1.22 , $1.16,1.12$, and 1.08 times greater than that of the M. chamomilla extract, while the potency levels based on the persistence of the different treatments descended as follows:

Table 3 Studies on the initial (Init.) and persistence (Pers.) reduction values of the high concentrations, the potency level and the susceptibility index of Aerosil $200^{\circledR}$ and four plant extracts applied to Thrips tabaci in an onion field

\begin{tabular}{|c|c|c|c|c|c|c|c|c|}
\hline \multirow[t]{2}{*}{ Compound } & \multicolumn{2}{|c|}{ Initial and Pers. reduction } & \multicolumn{3}{|c|}{ Potency level } & \multicolumn{3}{|c|}{ Susceptibility index } \\
\hline & Initial & Persistence* & Initial & Persistence & General mean & Initial & Persistence & General mean \\
\hline Aerosil $200^{\circledR}$ & 83.66 & 73.18 & 1.12 & 1.09 & 1.10 & 91 & 93 & 92 \\
\hline Trigonella foenum-graecum & 81.08 & 67.78 & 1.08 & 1.01 & 1.03 & 88 & 81 & 87 \\
\hline Mentha arvensis & 86.92 & 71.46 & 1.16 & 1.06 & 1.09 & 95 & 91 & 92 \\
\hline Matricaria chamomilla & 74.49 & 66.94 & 1.00 & 1.00 & 1 & 81 & 81 & 84 \\
\hline Cinnamomum camphora & 91.38 & 78.29 & 1.22 & 1.16 & 1.18 & 100 & 100 & 100 \\
\hline
\end{tabular}

*Persistence: average number of Thrips tabaci in treatments within interval time 3, 7, and 10 days 
Table 4 Effect of Cinnamomum camphora, Matricaria chamomilla, Mentha arvensis, and Trigonella foenum-graecum leaf extracts and Aerosil $200^{\circ}$ on the total chlorophyll, phenol, and protein concentrations ( $\left.\mathrm{mg} / \mathrm{g}\right)$ in onion plants after 10 days of spray application

\begin{tabular}{|c|c|c|c|}
\hline Compound & Chlorophylls (mg/g) & Phenol (mg/g) & Protein $(\mathrm{mg} / \mathrm{g})$ \\
\hline Control & $1.08^{c}$ & $2.15^{d}$ & $50.88^{d}$ \\
\hline C. camphora 4000 ppm & $1.20^{\mathrm{b}}$ & $4.65^{\mathrm{b}}$ & $67.50^{b}$ \\
\hline C. camphora 8000 ppm & $1.35^{\mathrm{a}}$ & $6.75^{\mathrm{a}}$ & $77.40^{\mathrm{a}}$ \\
\hline M. chamomilla 4000 ppm & $1.09^{c}$ & $3.15^{c}$ & $58.65^{c}$ \\
\hline M. chamomilla 8000 ppm & $1.17^{\mathrm{b}}$ & $4.78^{\mathrm{b}}$ & $64.40^{\mathrm{b}}$ \\
\hline M. arvensis 4000 ppm & $0.93^{e}$ & $3.15^{c}$ & $54.45^{c}$ \\
\hline M. arvensis 8000 ppm & $1.09^{c}$ & $4.21^{b}$ & $60.35^{\mathrm{b}}$ \\
\hline T. foenum-graecum 4000 ppm & $1.01^{d}$ & $2.85^{\mathrm{d}}$ & $57.75^{c}$ \\
\hline T. foenum-graecum 8000 ppm & $1.07^{c}$ & $4.10^{\mathrm{b}}$ & $63.15^{b}$ \\
\hline Aerosil $200^{\otimes} 2 \mathrm{ml} / \mathrm{l}$ & $1.11^{\mathrm{c}}$ & $3.70^{c}$ & $47.47^{e}$ \\
\hline Aerosil $200^{\circledR} 4 \mathrm{ml} / \mathrm{l}$ & $1.18^{\mathrm{b}}$ & $5.80^{\mathrm{a}}$ & $35.25^{\mathrm{e}}$ \\
\hline LSD (Least significant difference) & 0.6 & 1.25 & 4.25 \\
\hline
\end{tabular}

aighly significant at $P<0.01$

${ }^{\mathrm{b}}$ Significant at $P<0.5$

$c, d$, Non-significant at $P<0.5$ (there is no significant difference between data which given the same letter in the same column)

C. camphora, Aerosil $200^{\circ}$, M. arvensis, T. foenumgraecum, and M. chamomilla.

According to Sun (1950), the susceptibility index can describe and differentiate between treatments with a given arbitrary index value of 100 units for the most effective treatment. In this study, the most effective treatment was that with the C. camphora extract, so it considered the standard toxicant and given arbitrary index value of 100 units, and the reduction effect of tested compounds descended in the following order: $C$. camphora, M. arvensis, Aerosil $200^{\circ}$, T. foenum-graecum, and $M$. chamomilla. These results are in accordance with those of Shehawy et al. (2013), who concluded that plant extracts showed high reduction efficacy against $T$. tabaci.

\section{Effect of plant extracts on the chlorophyll, phenol, and total protein contents in onion plants Chlorophyll concentration}

As shown in Table 4, there was a significant difference observed in the total chlorophyll concentration of onion leaves after 10 days of application for all treatments. The total chlorophyll concentration in the control was 1.08, while it was $1.20,1.09,1.09,0.93,1.01$, and $1.11 \mathrm{mg} / \mathrm{g}$ dry weight, when the lowest concentrations of C. camphora, M. chamomilla, M. arvensis, T. foenum-graecum, and Aerosil $200^{\circ}$ were applied, respectively, and that after application of the highest concentrations was 1.35, 1.17, $1.09,1.07$, and $1.18 \mathrm{mg} / \mathrm{g}$ dry weight. Overall, it can be concluded that there was a direct relation between the application of C. camphora and M. chamomilla with the total chlorophyll concentration in the onions, i.e., the greatest applied extract concentration was the greatest total chlorophyll concentration compared to that of the control. However, no significant differences in the chlorophyll content were observed when the lowest concentrations of M. chamomilla, M. arvensis, and Aerosil $200^{\circ}$ were used compared to that of the control. Leaf senescence including chlorophyll loss (leaf yellowing) decreases the amount of photosynthesis occurring (Munne-Bosch 2007). Variations in the chlorophyll concentration of the plant may be due to the presence of some interactions of allelochemicals present in the plant extracts used in this study (Talukder et al. 2015).

\section{Phenol concentration}

The data in Table 4 show that the phenol concentration was $2.15,6.75,4.78,4.21$, and $4.10 \mathrm{mg} / \mathrm{g}$ dry weight, in onions after application of the lowest concentration of C. camphora, M. chamomilla, M. arvensis, T. foenumgraecum, and Aerosil $200^{\circ}$, respectively. And that after application of the highest concentrations was 4.65, 3.15, $3.15,2.85$, and $3.70 \mathrm{mg} / \mathrm{g}$ dry weight, respectively, after 10 days. It could be concluded that treatment with the highest concentrations of C. camphora and Aerosil $200^{\circ}$ correlated with a positive allelopathic effect (leading to increased phenol accumulation) compared to that of the control. However, application of M. arvensis and Aerosil $200^{\circ}$ exhibited a negative allelopathic effect and led to a low concentration of phenols in the onions. Phenols in plants are involved in diverse processes, such as UV protection, plant pigmentation, plant nitrogen fixation, and disease resistance in the plant. Additionally, phenols, including flavonoids, are considered antioxidants and are medically important Abreu and Munne'-Bosch S. (2009). A complex allelopathic effect may inhibit growth of other plant species. Allelopathy is plant competition; it involves biochemical interactions, and it can involve 
Table 5 Bands generated and polymorphism percentages obtained from RAPD-PCR primers of T. tabaci after exposure to high concentrations of plant extracts and Aerosol $200^{\circledR}$ at $4 \mathrm{ml} / \mathrm{l}$

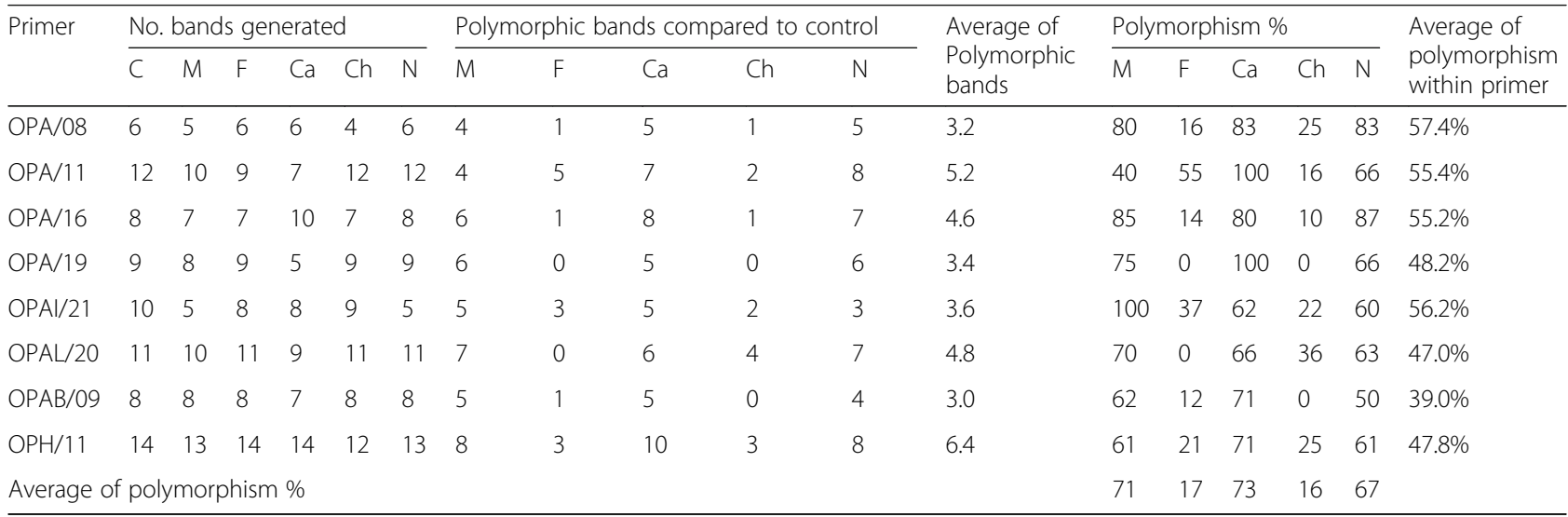

C, control; N, Aerosol 200 ${ }^{\oplus}$; Ca, Cinnamomum camphora; Ch Matricaria chamomilla; M, Mentha arvensis; F, Trigonella foenum-graecum

both "inhibitory" and "stimulatory" responses from the same compound (Leicach et al. 2009).

\section{Total protein}

The data illustrated in Table 4 show that the concentration of total proteins, measured after application of high concentrations of C. camphora, M. chamomilla, M. arvensis, T. foenum-graecum, and Aerosil $200^{\circ}$ on the onions was $77.4,64.4,60.35,63.25$, and $35.25 \mathrm{mg} / \mathrm{g}$ dry weight, respectively, whereas the total protein contents was 67.5 , $58.65,54.45,57.75$, and $47.47 \mathrm{mg} / \mathrm{g}$ dry weight, after application at low concentrations. The application of C. camphora at $8000 \mathrm{ppm}$ increased the protein concentration the most after 10 days of application, followed by $M$. chamomilla, $M$. arvensis, $T$. foenum-graecum, and $M$. arvensis. Application of the nanoparticles in Aerosil $200^{\circ}$ decreased the concentration of total protein, indicating that Aerosil $200^{\circ}$ had a negative allelopathic effect on the onions. However, the four plant leaf extracts exhibited beneficial allelopathic effects on the onion plant protein content. Overall, it could be concluded that there was a strong inverse relation between insect infestation and the chemical constituents of the onion plants after the treatments.

Allelopathy can affect many occurrences of plant bionomics, including growth, plant succession, and plant productivity (Singh et al. 2001).

\section{Molecular markers}

All eight RAPD-PCR primers used in the present study gave sufficient PCR banding patterns as shown in Table 5 and Fig. 1. DNA analysis based on the molecular marker technique is an effective method for studying the genetic diversity of insect pests (Loxdale and Lushai 1998). The main advantage of PCR-based systems is the development

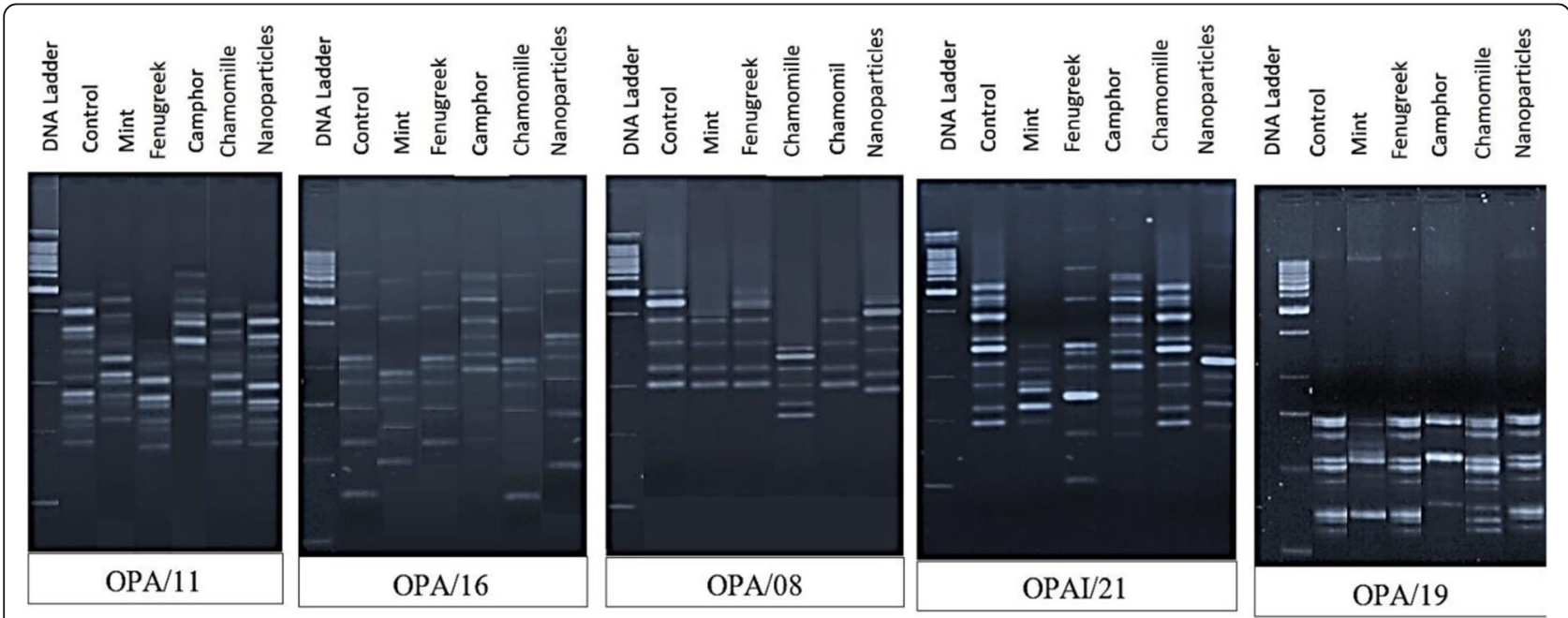

Fig. 1 Molecular polymorphism banding patterns of RAPD-PCR primers of T. tabaci after exposure to high concentrations of plant extracts and Aerosil $200^{\oplus}$ at $4 \mathrm{ml} / \mathrm{l}$ for 10 days (1 kb DNA ladder) 
of single and multiloci fragments, and all eight RAPD primers used in this study produced scorable PCR products by amplifying the template DNA of T. tabaci with Taq polymerase.

The results illustrated in Table 5 indicate that primer OPA/08 gave $6,5,6,6,4$, and 6 generated bands in the control, M. arvensis, T. foenum-graecum, C. camphora, M. chamomilla, and Aerosil $200^{\circ}$ groups, respectively. Moreover, OPA/11 gave 12, 10, 9, 7, 12, and 12 generated bands in the control, M. arvensis, T. foenumgraecum, C. camphora, M. chamomilla, and Aerosil $200^{\circ}$ groups, respectively, and OPA/16, OPA/19, OPAI/21, $\mathrm{OPAL} / 20, \mathrm{OPAB} / 09$, and $\mathrm{OPH} / 11$, gave generated bands in the control $(8,9,10,11,8$, and 14), $M$. arvensis $(7,8$, $5,10,8$, and 13), T. foenum-graecum $(7,9,8,11,8$, and 14), C. camphora (10,5, 8, 9, 7, and 14), M. chamomilla (7, 9, 9, 11, 8, and 12), and Aerosil $200^{\circ}(8,9,5,11,8$, and 13) groups.

Generally, the average number of polymorphic bands of the eight tested primers showed that the best harvested bands produced in RAPD-PCR were those of the primer $\mathrm{OPH} / 11$, which gave 6.4 bands, followed by those of OPA/11 and OPAL/20, which gave 5.2 and 4.8 bands, respectively. The lowest average number of polymorphic bands was produced by the primers OPAB/09, OPA/08, and OPA 19, which were 3, 3.2, and 3.4 bands, respectively (Table 5). Such a wide variation in the number of bands produced by these arbitrary primers may be attributed to the differences in the binding sites throughout the genome of T. tabaci.

Moreover, the polymorphism percentages in the present study indicated genetic changes in T. tabaci due to exposure to the different plant extracts as well as to the nanoparticles (Aerosil $200^{\circ}$ ). The results presented in Table 5 show that the polymorphism percentages were 73,71 , and $67 \%$ when the insects were treated with the highest concentration of the C. camphora and M. arvensis extracts and Aerosil $200^{\circ}$, respectively, whereas the $T$. foenum-graecum and $M$. chamomilla extracts induced the least polymorphism, yielding percentages of 17 and $16 \%$, respectively, when compared to that of the control.

The RAPD marker system distinguished the different impacts of different plant extractions and Aerosil $200^{\circ}$ as expected since they were affected on vitality of $T$. tabaci. This result was corroborated by the reduction percentage of onion infestation. This might be the host-induced genetic variation as observed in Thrips (Brunner et al. 2004).

Many studies have shown that there is a strong correlation between the genetic variation in the Thrips genome and changes in the DNA bands produced with RAPD (Jenser et al. 2001). The present study showed the ability of several plant extracts (C. camphora, $M$. arvensis( and nanoparticles to cause genetic changes in Thrips.
This result is consistent with that of many studies that suggested the ability of the Thrips genus to induce genetic modifications for pesticide resistance (Tsukahara et al. 2003), which may explain the global distribution of Thrips.

\section{Conclusion}

Overall, it can be concluded that using the aqueous leaf extracts, as well as the fumed silica nanoparticles had significant reduction effects on T. tabaci populations in an onion field. On the other hand, all of the plant extracts had positive allelopathic effects on onions by improving the chlorophyll, phenol, and protein contents in onion plants, but Aerosol $200^{\circ}$ application was shown to decrease the total protein content.

\section{Acknowledgements}

Not applicable

Authors' contributions

AS and SQ did the conceptualization. AS, SQ, NA, KA, and NA contributed in the formal analysis. AS, SQ, NA, KA, and NA took part in the investigation. AS and NA wrote the original draft. AS and SQ did the writing-review and approved the final manuscript. All authors read and approved the final manuscript.

\section{Funding}

The authors received no specific funding for this work.

\section{Availability of data and materials}

Data sharing is not applicable to this article as no datasets were generated or analyzed during the current study

Ethics approval and consent to participate

Not applicable

Consent for publication

Not applicable

\section{Competing interests}

The authors declare that they have no competing interests.

\section{Author details}

'Biology Department, Aljumum University College, Umm Al - Qura University, Makkah, Saudi Arabia. ${ }^{2}$ Plant Protection Research Institute, Agricultural Research Center, Giza, Egypt.

Received: 18 November 2019 Accepted: 10 February 2020

Published online: 17 February 2020

\footnotetext{
References

Abdelkhalek A, Qari S, Hafez E (2019) Iris yellow spot virus induced chloroplast malformation results in male sterility. J Biosci 44:142

Abreu ME, Munne'-Bosch S (2009) Salicylic acid deWciency in NahG transgenic lines and sid2 mutants increases seed yield in the annual plant Arabidopsis thaliana. J Exp Bot 2:1-11

Adakole JA and Adeyemi AFF (2012) Larvicidal effects of cymbopogon citratus (lemon grass) extract against Culex quinquefasciatus qularvae (Diptera, culicidae). IJAES 7: 187-192.

Brunner PC, Chatzivassiliou EK, Katis NI, Frey JE (2004) Host-associated genetic differentiation in Thrips tabaci (Insecta: Thysanoptera), as determined from mtDNA sequence data. Heredity 93:364-370

Denre M (2014) The determination of vitamin C, total phenol and antioxidant activity of some commonly cooking spices crops used in West Bengal. Inter j of Physiology and Biochemistry 6(6):66-70
} 
Gent DH, du Toit L, Fichtner SF, Mohan SK, Pappu HR, Schwartz HF (2006) Iris yellow spot virus: an emerging threat to onion bulb and seed production Plant Dis 90:1468-1480

Hanan M. AE-G (2016) Physiological allelopathic effect of aqueous extracts of cucumber, carrot, onion, and garlic seeds on germination and growth of pea. J Pharm Chem Biol Sci 4(1):13-19

Henderson CF, Tilton EW (1955) Tests with acaricides against the brow wheat mite. J Econ Entomol 48:157-161

Jensen L (2005) Insectiside trials for onion Thrips (Thrips tabaci) control. Malheur Experiment Station Annual Report:71-76

Jenser G, Szénási A, Törjek O, Gyulai G, Kiss E, Heszky L, Fail J (2001) Molecular polymorphism between population of Thrips tabaci Lindeman (Thysanoptera: Thripidae) propagating on tobacco and onion. Acta Phytopathol Entomol Hung 36(3-4):365-368

Knekt P, Järvinen R, Reunanen A, Maatela J (1996) Flavonoid intake and coronary mortality in Finland. a cohort study. Br Med J 312:478-481

Kranthi KR, Jadhav DR, Wanjari RR, Ali S, Russell D (2002) Insecticide resistance in five major insect pests of cotton in India. Crop Prot 21:449-460

Leicach SR, Sampietro DA, Narwal SS (2009) Allelochemicals: role in plant environment interactions. Studium Press, Houston, USA

Loxdale HD, Lushai G (1998) Molecular markers in entomology. Bull Entomol Res 88:577-600

Luceri C, Filippo D, Caderni G, Gambacciani L, Salvadori M, Giannini A, Dolara P (2000) Detection of somatic DNA alterations in azoxymethane-induced F344 rat colon tumors by random amplified polymorphic DNA analysis. Carcinogenesis 2(1):1753-1756

Martínez MC, Corzo N, Villamie I.M. (2007) Biological properties of onions and garlic. Trends Food Sci Technol 18(12):609-625

Metzner H, Rau H, Senger H (1965) Untersuchungen zur synchronisier barteit einzelner pigmentanangel-mutanten von chlorella. Planta 65:186

Munne-Bosch S (2007) Aging in perennials. Crit Rev Plant Sci 26:123-138

Murray Bl, Saber M, Cristina M (2011) Commercial opportunities for pesticides based on plant essential oils in agriculture, industry and consumer products. Phytochemistry Reviews 10(2):197-202

Oliveira L, Ricardo T, Claudete F (2010) Genetic Analysis of Species in the Genus Catasetum (ORCHIDACEAE) using RAPD Markers. Arch Biol Technol 53(2): 375-387

Pappu HR, Rosales IM, Druffel KL (2008) Serological and molecular assays for rapid and sensitive detection of Iris yellow spot virus infection of bulb and seed onion crops. Plant Dis 92:588-594. https://doi.org/10.1094/PDIS-92-40588

Qari S, Abdel-Fattah N (2017) Genotoxic studies of selected plant oil extracts on Rhyzopertha dominica (Coleoptera: Bostrichidae). Journal of Taibah University for Science (JTUSCI) 11:478-486. https://doi.org/10.1016/j.jtusci.2016.09.010

Qari SH (2008) Assessment of the potential genotoxic risk and antigenotoxic effect of Cassia senna L. Leaves aqueous extract using in vitro assays. Egypt J Biotechnol 30:101-116

Qari S. H. (2010). RAPD fingerprinting and cytogenetic screening of genotoxic and antigenotoxic effects of aqueous extracts of Costus speciosus (Koen.) JKAU Sci 22(1): 133-152. DOI: 10.4197 / Sci. 22-1.10.

Qari SH (2016) Cytotoxic and genotoxic assessment of Citrullus colocynthis. International Journal of Scientific Research and Reviews (IJSRR) 5(2):20-39

Ramakrishnan MN, Abhay KP, Abdul RW, Bindumadhava H, Tun S, Akmm A, Aditya P, Malik SR, Rael K, Emmanuel KM, Colin AD, Jagadish R, Roland S (2019) Biotic and abiotic constraints in mungbean production-progress in genetic improvement. Front Plant Sci 10:1340-1363 https:/doi.org/10.3389/ fpls.2019.01340

Shehawy AA, Mohamed HA, Ahmed MA (2013) Evaluation of some botanical oils against Thrips tabaci on onion field in Egypt. Egypt J of Appl Sci 28(7):130139

Singh BN, Singh BR, Singh RL, Prakash D, Singh DP, Sarma BK, Upadhyay G, singh HB (2009) Polyphenolics from various extracts/fractions of red onion (Allium cepa) peel with potent antioxidant and antimutagenic activities. Food Chem Toxicol 47(6):1161-1167

Singh HP, Batish DR, Kohli RK (2001) Allelopathy in agroecosystems. An overview. J Crop 4:1-41

Stepanycheva E, Petrova M, Chermenskaya T (2019) Fumigant effect of essential oils on mortality and fertility of thrips Frankliniella occidentalis Perg. Environ Sci Pollut Res 26:30885-30892

Sun YP (1950) Toxicity index-an improved method of comparing the relative toxicity of insecticides. J Econ Entomol 557:92-108
Talukder MAl, Rahaman M, Roy B, Saha KC (2015) Effects of herbal plant extracts on germination and seedling growth of some vegetables. I I S N 6(3):421425

Tsukahara Y, Sonoda S, Fujiwara Y, Nakasuji F, Tsumuki H (2003) Molecular analysis of the para-sodium channel gene in the pyrethroid-resistant diamondback moth, Plutella xylostella (Lepidoptera: Yponomeutidae). Appl Entomol Zool 38:23-29

\section{Publisher's Note}

Springer Nature remains neutral with regard to jurisdictional claims in published maps and institutional affiliations.

\section{Submit your manuscript to a SpringerOpen ${ }^{\circ}$ journal and benefit from:}

- Convenient online submission

- Rigorous peer review

- Open access: articles freely available online

High visibility within the field

- Retaining the copyright to your article

Submit your next manuscript at $\boldsymbol{\nabla}$ springeropen.com 